\title{
Bacteriological Quality of Mozzarella Cheese Sold in Tripoli Governorate
}

\author{
A. M. Garbaj ${ }^{1}$, H. T. Naas ${ }^{1}$, F.T. Gammoudi ${ }^{2}$, A. A. Moawad ${ }^{1 *}$ \\ ${ }^{1}$ Department of Food Hygiene, El-Fateh University, Tripoli, Libya \\ ${ }^{2}$ Department of Microbiology and Parasitolog, El-Fateh University, Tripoli, Libya
}

\begin{abstract}
Thirty samples of Mozzarella cheese (15 made traditionally from raw milk in Tripoli city (Libya) and other 15 imported samples sold in markets related to different brand names) were examined bacteriologically for their total bacterial count, psychrophilic count, coliform count (MPN/g), presumptive Staphylococcus aureus count, as well as enterococci count. Higher counts were found in locally manufactured Mozzarella cheese. Salmonellae were absent in all examined samples for both types, while Escherichia coli were isolated from 3 samples (20\%) of locally made samples. According to the suggested Libyan Standards of such samples, most of examined locally manufactured Mozzarella cheese samples were found unacceptable.
\end{abstract}

Although Mozzarella cheese is one of several pasta filata cheeses that originated in Italy, it is consumed worldwide, largely due to the growth in popularity of pizza and similar foods (Bertola et al., 1996). Pasta filata cheeses are distinguished by a unique plasticizing and kneading treatment of the fresh curd in hot water, which imparts to the finished cheese its characteristic fibrous structure, melting and stretching properties (Fox, 1993).

It is very difficult to produce a high quality product using traditional method for manufacture of cheese due to lack of standardization of most manufacturing steps, especially the ripening conditions (Dervisoglu and Yazici, 2001). On the other hand, using pasteurized milk and starter culture in large scale production (imported type Mozzarella cheese) improves the keeping quality and significantly reduces pathogens in comparison with using raw milk in traditional method (Petracca et al., 1983). In General, Mozzarella cheese has a brief shelf-life (20 - 30 days) that depending on the extent and degree of refrigerated storage (Massa et al., 1992; Kosikowski and Mistry, 1997).

Mostly, Mozzarella cheese is stored in refrigerator at $5^{\circ} \mathrm{C}$ in retail shops, fresh cheese is typically firm and has poor melting properties

* Corresponding author. Tel.: +2 18925238875

E-mail address: ashrafm222@hotmail.com (A. A. Moawad). and although it will stretch, the overall texture will be unacceptable. However, as the cheese ages over a period of three weeks the texture becomes most suitable for preferable rheological properties (Rowney et al., 1999). Mozzarella cheese stored for longer period becomes extremely soft and fluid when melted and is no longer acceptable for pizza (Kindstedt, 1993), in addition with such longer storage period, some bacterial population increases and much of which are undesirable, causing spoilage of the cheese or may be pathogenic, representing public health hazard to consumers.

Many outbreaks due to the consumption of Mozzarella cheese were reported (Salvatore et al., 1992).

According to the suggested Libyan standards, the shelf-life of Mozzarella cheese stored in refrigerator $\left(5^{\circ} \mathrm{C}\right)$ is one month in comparison with one year shelf-life for that stored at $-18^{\circ} \mathrm{C}$. Therefore, this work was planned to examine and compare the Mozzarella cheese made locally by traditional method in Tripoli city and that imported from different countries to the Libyan markets and its satisfaction to the known microbial limits suggested by Libyan Organization for Standardization.

Because only limited studies were previously conducted on Mozzarella cheese in Libyan Arab Jamahiriya, the aim of this study was to evaluate the bacterial quality of Mozzarella cheese sold in Libyan markets, either 


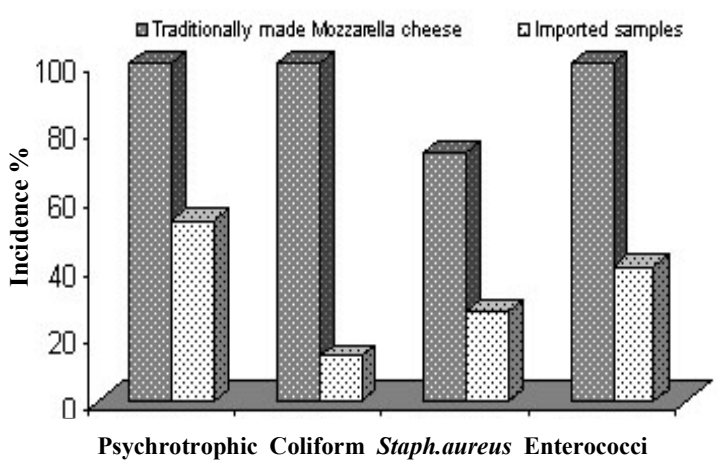

Fig. (1): Incidence percent of different examined microbial groups among examined samples of Mozzarella cheese.

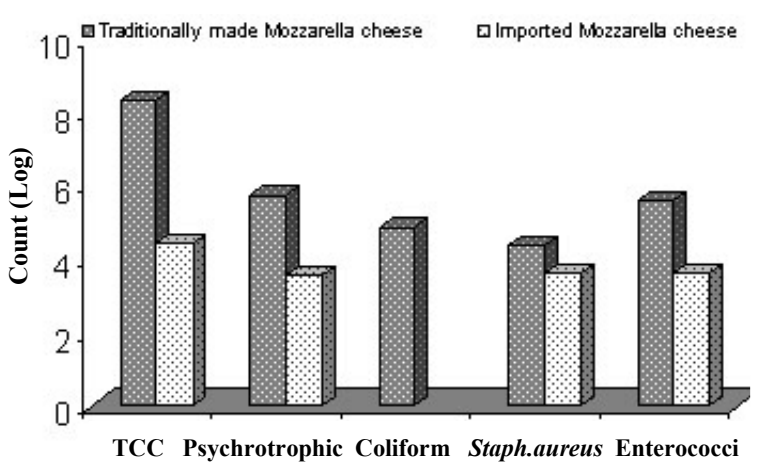

Fig. (2): Mean microbial group counts per gram "log" for positive samples of Mozzarella cheese made by both traditional method and imported samples.

Table (1): Statistical analytical results of different bacterial counts (CFU/g) in examined Mozzarella cheese samples made by traditional method. (No. of samples $=15$ ).

\begin{tabular}{lccccc}
\hline \multirow{2}{*}{ Counts } & \multicolumn{2}{c}{ Positive samples } & \multirow{2}{*}{ Minimum } & Maximum & \multirow{2}{*}{ Mean Count } \\
\cline { 2 - 3 } & No. & \% & & & \\
\hline Total Colony Count & 15 & 100 & $1.06 \times 10^{5}$ & $3.2 \times 10^{9}$ & $8.5 \times 10^{7} \pm 1.3 \times 10^{7}$ \\
Psychrotrophic Count & 15 & 100 & $3 \times 10^{4}$ & $4.8 \times 10^{7}$ & $5.8 \times 10^{5} \pm 0.65 \times 10^{5}$ \\
Coliform Count & 15 & 100 & $3.3 \times 10^{3}$ & $1.1 \times 10^{5}$ & $7.3 \times 10^{4} \pm 0.95 \times 10^{4}$ \\
Staphylococcus aureus & 11 & 73.33 & 30 & $1.7 \times 10^{6}$ & $2.3 \times 10^{4} \pm 0.27 \times 10^{4}$ \\
(Presumptive count) & 15 & 100 & $1.8 \times 10^{3}$ & $7.6 \times 10^{7}$ & $3.8 \times 10^{5} \pm 0.85 \times 10^{5}$ \\
Enterococci count & 15 & & & & \\
\hline
\end{tabular}

Table (2): Statistical analytical results of different bacterial counts (CFU/g) in examined Mozzarella cheese samples made by modern dairy plants (imported samples) (No. of samples $=15$ ).

\begin{tabular}{lccccc}
\hline \multicolumn{1}{c}{ Counts } & \multicolumn{2}{c}{ Positive samples } & \multirow{2}{*}{ Minimum } & Maximum & \multirow{2}{*}{ Mean Count } \\
\cline { 2 - 3 } & No. & $\mathbf{\%}$ & & & \\
\hline Total Colony Count & 15 & 100 & $2 \times 10^{5}$ & $6.5 \times 10^{7}$ & $2.7 \times 10^{6} \pm 0.44 \times 10^{6}$ \\
Psychrotrophic Count & 8 & 53.33 & 60 & $7.4 \times 10^{4}$ & $3.7 \times 10^{3} \pm 0.29 \times 10^{3}$ \\
Coliform Count & 2 & 13.33 & 2 & $1.6 \times 10^{3}$ & NA $^{*}$ \\
$\begin{array}{l}\text { Staphylococcus aureus } \\
\text { (Presumptive count) }\end{array}$ & 4 & 26.66 & 30 & $1.8 \times 10^{4}$ & $4.2 \times 10^{3} \pm 0.36 \times 10^{3}$ \\
Enterococci count & 5 & 33.33 & 40 & $3.1 \times 10^{4}$ & $4.1 \times 10^{3} \pm 0.31 \times 10^{3}$ \\
\hline
\end{tabular}

*NA:No statistical analysis due to few positive samples.

locally made "traditional types", or of imported origin, thus providing a national data about bacteriological quality of such cheese.

\section{Materials and Methods}

Collection of samples. Thirty samples of Mozzarella cheese; 15 samples were obtained from dairy plant produce Mozzarella cheese from raw milk using traditional method and 15 samples of packed imported retail samples obtained from Tripoli markets. Samples were collected and transferred to the laboratory for bacteriological examination.
Preparation of samples and decimal dilutions. Sample preparation was performed according to the method described by (APHA, 1992).

Psychrotrophic count. It was determined in a similar method to that of APC except that plates were incubated at $7^{\circ} \mathrm{C}$ for 10 days (Cousin et al., 1992).

Coliforms count (MPN/g). It was done using lauryl sulphate tryptone broth according to (APHA, 1992). Coliform isolates were biochemically identified according to (Krieg and Holt, 1984).

Enterococci count. It was made using ESD 
Table (3): Frequency distribution of the different microbial counts in examined Mozzarella cheese made locally by traditional method.

\begin{tabular}{|c|c|c|c|c|c|c|c|c|c|c|}
\hline \multirow{3}{*}{ Intervals } & \multicolumn{10}{|c|}{ Bacterial counts (CFU/g) } \\
\hline & \multicolumn{2}{|c|}{ Total colony count } & \multicolumn{2}{|c|}{ Psychrotrophic count } & \multicolumn{2}{|c|}{ Coliform count } & \multicolumn{2}{|c|}{$\begin{array}{c}\text { Staphylococcus aureus } \\
\text { count }\end{array}$} & \multicolumn{2}{|c|}{ Enterococci count } \\
\hline & No. & $\%$ & No. & $\%$ & No. & $\%$ & No. & $\%$ & No. & $\%$ \\
\hline$<10$ & 0 & 0 & 0 & 0 & 0 & 0 & 4 & 26.67 & 0 & 0 \\
\hline $10-<10^{2}$ & 0 & 0 & 0 & 0 & 0 & 0 & 1 & 6.67 & 0 & 0 \\
\hline $10^{2}-<10^{3}$ & 0 & 0 & 0 & 0 & 0 & 0 & 2 & 13.33 & 0 & 0 \\
\hline $10^{3}-<10^{4}$ & 0 & 0 & 0 & 0 & 3 & 20 & 2 & 13.33 & 3 & 20 \\
\hline $10^{4}-<10^{5}$ & 0 & 0 & 1 & 6.67 & 8 & 53.34 & 3 & 20 & 2 & 13.33 \\
\hline $10^{5}-<10^{6}$ & 1 & 6.67 & 11 & 73.33 & 4 & 26.66 & 1 & 6.67 & 7 & 46.67 \\
\hline $10^{6}-<10^{7}$ & 4 & 26.66 & 2 & 13.33 & 0 & 0 & 2 & 13.33 & 2 & 13.33 \\
\hline $10^{7}-<10^{8}$ & 6 & 40 & 1 & 6.67 & 0 & 0 & 0 & 0 & 1 & 6.67 \\
\hline $10^{8}-<10^{9}$ & 4 & 26.67 & 0 & 0 & 0 & 0 & 0 & 0 & 0 & 0 \\
\hline Total & 15 & 100 & 15 & 100 & 15 & 100 & 15 & 100 & 15 & 100 \\
\hline
\end{tabular}

Table (4): Frequency distribution of the different microbial counts in examined imported Mozzarella cheese.

\begin{tabular}{|c|c|c|c|c|c|c|c|c|c|c|}
\hline \multirow{3}{*}{ Intervals } & \multicolumn{10}{|c|}{ Bacterial counts (CFU/g) } \\
\hline & \multicolumn{2}{|c|}{ Total colony count } & \multicolumn{2}{|c|}{ Psychrotrophic count } & \multicolumn{2}{|c|}{ Coliform count } & \multicolumn{2}{|c|}{$\begin{array}{c}\text { Staphylococcus aureus } \\
\text { count }\end{array}$} & \multicolumn{2}{|c|}{ Enterococci count } \\
\hline & No. & $\%$ & No. & $\%$ & No. & $\%$ & No. & $\%$ & No. & $\%$ \\
\hline$<10$ & 0 & 0 & 7 & 46.67 & 14 & 93.33 & 11 & 73.33 & 10 & 66.66 \\
\hline $10-<10^{2}$ & 0 & 0 & 1 & 6.67 & 0 & 0 & 1 & 6.67 & 1 & 6.67 \\
\hline $10^{2}-<10^{3}$ & 0 & 0 & 2 & 13.33 & 0 & 0 & 0 & 0 & 1 & 6.67 \\
\hline $10^{3}-<10^{4}$ & 0 & 0 & 4 & 26.66 & 1 & 6.67 & 2 & 13.33 & 2 & 13.33 \\
\hline $10^{4}-<10^{5}$ & 0 & 0 & 1 & 6.67 & 0 & 0 & 1 & 6.67 & 1 & 6.67 \\
\hline $10^{5}-<10^{6}$ & 3 & 20 & 0 & 0 & 0 & 0 & 0 & 0 & 0 & 0 \\
\hline $10^{6}-<10^{7}$ & 10 & 66.67 & 0 & 0 & 0 & 0 & 0 & 0 & 0 & 0 \\
\hline $10^{7}-<10^{8}$ & 2 & 13.33 & 0 & 0 & 0 & 0 & 0 & 0 & 0 & 0 \\
\hline Total & 15 & 100 & 15 & 100 & 15 & 100 & 15 & 100 & 15 & 100 \\
\hline
\end{tabular}


Table (5): Incidence of isolated coliforms from both types of Mozzarella cheese.

\begin{tabular}{lcccc}
\hline \multirow{2}{*}{ Mozzarella cheese } & \multicolumn{2}{c}{ Traditionally made } \\
No. = 15 & No. & \% & No. & Imported \\
\cline { 2 - 5 } Isolated organism & & 20 & 0 & 0 \\
\hline Coliform Isolates: E. coli & 3 & 40 & 1 & 6.67 \\
Klebsiella pneumoniae & 6 & 13.33 & 1 & 6.67 \\
K. oxytoca & 2 & 13.33 & 0 & 0 \\
K. ozaenae & 2 & 6.67 & 0 & 0 \\
K. rhinoscleromatis & 1 & 26.66 & 0 & 0 \\
Enterobacter aerogens & 4 & 6.67 & 1 & 6.67 \\
Enterobacter cloacae & 1 & 26.66 & 0 & 0 \\
Citrobacter diversus & 4 & 20 & 0 & 0 \\
Citrobacter freundii & 3 & 6.67 & 0 & 0 \\
Citrobacter amalonaticus & 1 & & & 0 \\
\hline
\end{tabular}

media (Enterococci selective differential media) by the technique described by (Efthymiou et al., 1974).

Staphylococcus aureus presumptive count. It was made using Baird-Parker agar according to (Lancette and Tatini, 1993). The technique adopted by (Flowers et al., 1992) for isolation of Salmonella species was used by pre-enrichment in trypticase soya broth with yeast extract (TSBYE) followed by selective enrichment in Rappaport broth, and selective plating on XLD agar plates.

\section{Results and Discussion}

Although imported Mozzarella cheese contains starter culture, the mean total bacterial count $\left(2.7 \times 10^{6} \mathrm{CFU} / \mathrm{g}\right)$ is lower than that of traditionally made Mozzarella cheese using raw milk $\left(8.5 \times 10^{7} \mathrm{CFU} / \mathrm{g}\right)$ (Table 1, 2, Fig.2). The highest frequency distribution was $40 \%$ for traditionally made type and $66.67 \%$ for imported type and lies within the range of $10^{7}-<10^{8}$ and $10^{6}-<10^{7}$ for both types respectively (Tables 3 , 4). This may explain the high rate of contamination of the traditionally made Mozzarella cheese due to using raw milk in manufacturing process and the effect of using pasteurization process in reducing bacterial population in imported Mozzarella cheese before adding starter culture. These results were in agreement with that obtained by (Petracca et al., 1983; Warke et al., 1999; Soliman, 2002).

Concerning psychrotrophic count, all examined Mozzarella cheese were positive for traditionally made cheese, with a minimum of $3 \times 10^{4}$ and maximum of $4.8 \times 10^{7}$ with a mean count of $5.8 \times 10^{5} \pm 0.65 \times 10^{5}$, while for imported types only 8 samples $(53.33 \%)$ were positive, the mean count was $3.7 \times 10^{3} \pm 0.29 \times 10^{3}$.

The length of refrigerated storage $\left(2{ }^{\circ} \mathrm{C}\right)$ has a significant effect on psychrotrophic count which tend to increase (Sallam and Samejima, 2004; Fang et al., 2006). Psychrotrophic bacteria produce enzymes capable of hydrolyze proteins in Mozzarella cheese (Dervisoglu and Yazici, 2001).

Regarding coliforms in traditionally made Mozzarella cheese, the incidence was (100\%) in all examined samples as compared with 2 samples (13.33\%) for modern made Mozzarella cheese, with mean count (MPN/gram) for positive samples of $7.3 \times 10^{4} \pm 0.95 \times 10^{4} \mathrm{CFU} / \mathrm{g}$ for traditionally made Mozzarella cheese, no statistical results were obtained for imported samples as the positive samples are too few (Tables 1, 2, Fig. 1, 2), the higher frequency distribution lies between $10^{4}$ and $<10^{5}(53.34 \%)$ for traditionally made Mozzarella cheese (Table $3)$.

The counts for positive samples were much higher than limits suggested by Libyan Organization for Standardization for Mozzarella cheese (not exceeding 10 coliforms/g). Similar results were obtained by El-Prince and Ismail, (1998), while higher counts were obtained by Massa et al. (1992) and Soliman, (2002). Different coliform members were isolated in different percentages including Klebsiella species, Enterobacter species, Citrobacter species.

Escherichia coli was isolated from three samples (20\%) of traditionally made Mozzarella cheese, while non was isolated from imported 
type Mozzarella cheese (Table 5).

Presence of coliforms indicates unsanitary conditions of production, handling, distribution and neglected hygienic measures. In addition, many members of coliforms are responsible for gassy holes in Mozzarella cheese (Massa et al., 1992), where Klebsiella species are responsible for spoilage and swelling of the plastic pouches for this type of cheese (Salvatore et al., 1992).

On the other hand, many E. coli strains were frequently associated with haemorrhagic colitis and haemolytic uraemic syndrome (HUS) (Griffin and Tauxe, 1991), and the presence of the organism is an indication of faecal contamination from human or animal sources (Armstrong et al., 1996) and contact with water and soil contaminated with ruminant manure (Coia, 1998 and Tozzi et al., 2001).

Staphylococcus aureus was present in 11 samples $(73.33 \%)$ of traditionally made Mozzarella cheese, while present only in 4 samples (26.66\%) of imported Mozzarella cheese with a mean count of $2.3 \times 10^{4}$ and $4.2 \times 10^{3} \mathrm{CFU} / \mathrm{g}$ in positive examined samples of both types respectively (Tables 1,2, Fig. 1,2). The highest frequency distribution of positive samples $(20 \%)$ lies between $10^{4}$ and $<10^{5}$ for the first type and lies between $10^{3}$ and $<10^{4}$ for the later type (13.33\%) (Tables 3,4). Nearly similar results were obtained by De Luca et al. (1997). Presence of Staphylococcus aureus in higher number may cause food poisoning due to production of enterotoxins (Tsung and Huang, 1993).

It is worth mentioning that the Libyan standards do not specify limits for such important organism count.

Enterococci was found in all examined Mozzarella cheese traditionally made while present in only 5 samples of imported samples $(33.33 \%)$, the mean counts were $3.8 \times 10^{5}$ and $4.1 \times 10^{3}$ for both types respectively.

Salmonellae could not be detected in any of examined Mozzarella cheese samples of both types.

Most of Enterococci are relatively heat resistant and may survive milk pasteurization (Hartman et al., 1992). This may explain the higher incidence (33.33\%) and count in imported types Mozzarella cheese as compared with other microbial groups for the same type of cheese. In addition most of Enterococci are also relatively resistant to freezing (APHA, 1992).
Presence of Enterococci is indicative for faecal contamination and consequently unsatisfactory production and handling (Moawad and El- Neary, 1996). Enterococci are also implicated in food poisoning (ICMSF, 1986) and can cause serious illness in human (Hoffman and Moellering, 1987).

Thus, it is important to focus the attention upon the quality of the raw milk before processing to ensure the quality of the end product made from it. Also, the unsatisfactory conditions of processing, handling and distribution of traditionally made Mozzarella cheese in addition to the lack of efficient veterinary supervision upon foods originated from animal origin may explain the obtained result in this work, therefore it is recommended to have specific standards for Mozzarella and other food products in Libyan Arab Jamahiriya for judging such product (s) and for supporting the food roles and laws, thus it is suggested to set the standards as quickly as possible.

In conclusion, the use of appropriate hygienic procedure, e.g. Hazard Analysis Critical Control Point system (HACCP) during processing should reduce the likelihood of higher microbial count and possibility of associated outbreaks.

\section{References}

APHA "American Public Health Association"(1992): Compendium of Methods for the Microbiological Examination of Foods. $2^{\text {nd }}$ ed., APHA, Washington D. C., USA.

Armstrong, G.L.; Hollingsworth, J. and Morris Jr. (1996): Emerging food borne pathogens: Escherichia coli O157:H7 as a model of entry of a new pathogen into the food supply of the developed country. Epidemiol. Rev., 18: 29-51.

Bertola, N. C.; Califano, A. N.; Bevilacqua, A. E. and Zaritzky, N. E. (1996): Effect of freezing conditions on functional properties of low moisture Mozzarella cheese. J. Dairy Sci., 79: 185-190.

Coia, J.E., (1998): Clinical, microbiological, and epidemiological aspects of Escherichia coli $\mathrm{O} 157$ infection. FEMS Immunol.Med. Microbiol., 20: 1-9.

Cousin, M. A.; Jay, J. M. and Vasavada, P. C. (1992): Psychrotrophic microorganisms. In C. Vanderzand, \& D. F. Splittstoesser (eds.), Compendium of Methods for the Microbiological Examination of Foods (3rd ed.) (pp. 153168). Washington, DC: Am. Pub. Health Assoc.

De Luca, G.; Zanetti, F. and Stampi, S. (1997): Staphylococcus aureus in dairy products in the Bologna area. Int. J. Food Microbiol., 35: 267-270.

Dervisoglu, M. and Yazici, F. (2001): Ripening changes of Kulek cheese in wooden and plastic containers. J. Food Eng., 48: 243-249.

Efthymiou, C. J.; Baccash, P.; Labombardi, V. J. and Epitein, D. S. (1974): Improved isolation and differentiation of enterococci in cheese. Appl. Microbiol., 28: 417-422. 
El-Prince, E. and Ismail, M. A. (1998): Microbiological quality of Mozzarella cheese. Assiut Vet. Med. J., 39: 94 109.

Fang, L.; Yi-zhi, G. and Yun-fei, L. (2006) : Interactions of microorganisms during natural spoilage of pork at $5^{\circ} \mathrm{C}$. J. Food Eng., 72: 24-29.

Flowers, R. S.; D'Aoust, J. Y.; Anderwa, W. H. and Bailey, J. S., (1992): Salmonella, Chapter 25. In Compendium of Methods for Microbiological Examination of Foods. Vanderzant, C. and Splittoesser, D. (eds). $3^{\text {rd }}$ ed. American Public Health Association, Washington, DC, USA.

Fox. P. F. (1993): Mozzarella and Pizza cheese. In Cheese: Chemistry, Physics and Microbiology, Vol. 2, Major cheese groups, $2^{\text {nd }}$ ed., P. F. Fox (ed.). Chapman \& Hall Publication, London, UK.

Griffin, P. M. and Tauxe, A. V. (1991): The epidemiology of infections caused by Escherichia coli O157:H7, other enterohemorrhagic E. coli and the associated hemolytic uremic syndrome. Epidemiol. Rev., 13: 60-98.

Hartman, P. A.; Deibel, R. H. and Sieverding, L.M. (1992): Enterococci in Compendium of Methods for the Microbiological Examination of Foods. $3^{\text {rd }}$ ed. American Public Health Association, Washington, D. C., USA.

Hoffman, S. A. and Moellering, R. C. Jr. (1987): The Enterococci: "Putting the bug in our ears" Ann. Intern. Med., 106: 757.

ICMSF "International Committee on Microbiological Specifications for Foods", (1986): Microorganisms in Foods. I. Their Significance and Methods of Enumeration. $2^{\text {nd }} e d$., Univ. of Toronto Press, Toronto, Buffalo and London.

Kindstedt, P. S. (1993): Effect of manufacturing factors, composition, and proteolysis on the functional characteristics of Mozzarella cheese. Crit Rev. Food Sci. Nutr., 33: 167-187.

Kosikowski, F. V. and Mistry, V. V. (1997): Cheese and Fermented Milk Foods, Vol. 2, Procedures and Analysis, F.V. Kosikowski, L. L. C., Westport, CT, pp. 223-224.

Krieg, N. R. and Holt, J. G. (1984): Bergey's Manual of Systemic Bacteriology. Vol. 1, Williams and WilkinsBaltimor, USA.
Lancette, G. A. and Tatini, S. R. (1993): Staphylococcus aureus Chapter 33, In Compendium of Methods for the Microbiological Examination of Foods. Inc. $4^{\text {th }}$ ed., New York, Vanderzantic, C and Splittstoesser, D. (Eds.) American Public Health Association, Washington, DC, USA.

Massa, S.; Gardini, F.; Sinigaglia, M. and Guerzoni, M. E. (1992): Klebsiella pneumoniae as a spoilage organism in Mozzarella cheese. J. Dairy Sci., 75: 1411-1414.

Moawad, A. A. and El- Neary, N. A. (1996): Microbial studies on creamy "Kishda" cheese sold in Egyptian markets. Benha Vet. Med., J. 2: 7.

Petracca, G.; Prochowski, D.; Martino, M.; Mozaaeo, A.; Petrunti, M.F.; Riccio, M.-det and Viscara, D. (1983): Hygiene control in the production of Molise Mozzarella cheese. Latte, 8 (7/8): 522-524.

Rowney, M.; Roupas, P.; Hickey, M. W. and Everett, D.W. (1999): Factors affecting the functionality of Mozzarella cheese. Australian J. Dairy Tech., 54: 94-102.

Sallam, K. I. and Samejima, K. (2004): Microbiological and chemical quality of ground beef treated with sodium lactate and sodium chloride during refrigerated storage. Lebensm.-Wiss. u.-Technol., 37: 865-871.

Salvatore, M.; Fausto, G.; Milena S.; and Maria, E. (1992): Klebsiella pneumoniae as a spoilage organism in Mozzarella cheese. J. Dairy Sci., 75: 1411-1414.

Soliman, N. M. S. (2002): Hygienic quality of Mozzarella cheese in Egyptian markets. MVSc. Thesis, Fac. Vet. Med., Cairo University. Egypt.

Tozzi, A. E., Gorietti, S. and Caprioli, A. (2001): Epidemiology of human infections by Escherichia coli O157 and other verocytotoxin- producing E. coli. In: Duffy, G., Garvey, P., McDowell, D. (Eds.), Verocytotoxigenic Escherichia coli. Food \& Nutrition Press, Trumbull, Connecticut, USA, pp. 161-179.

Tsung, C. and Huang, S. U. H. (1993): An immune linked immunosorbant assay for rapid detection of Staphylococcus aureus in processed food. J. Food Prot., 75: 184-189.

Warke, R. G.; Kamet, A. S. and Kamet, M. Y. (1999): Irradiation of cheese for improvement of microbiological quality. J. Food Prot., 62: 781-788.

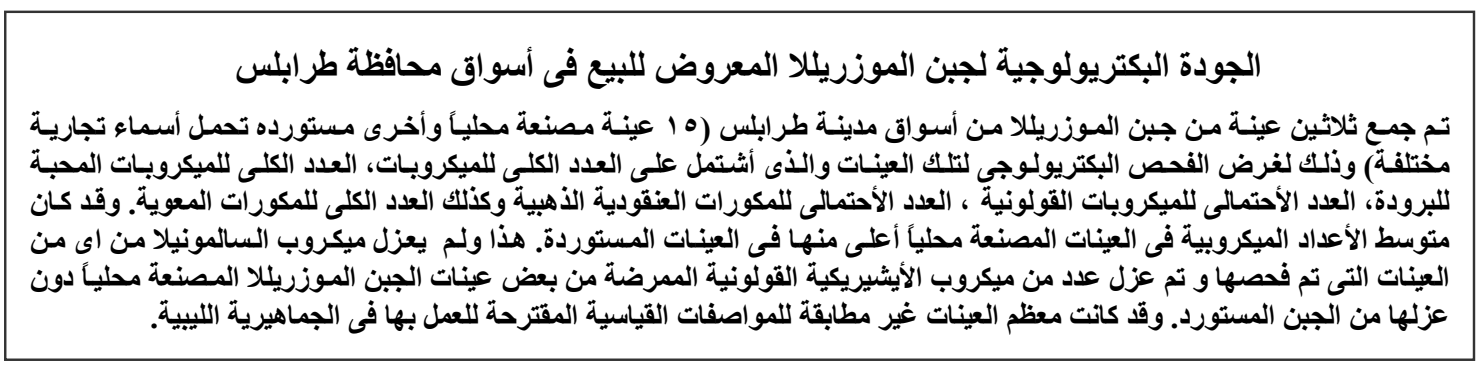

